\title{
sciendo
}

DOI 10.2478/sbe-2020-0008

SBE no. 15(1) 2020

\section{EVALUATION OF AIRLINES PERFORMANCE USING AN INTEGRATED CRITIC AND CODAS METHODOLOGY: THE CASE OF STAR ALLIANCE MEMBER AIRLINES}

\author{
KIRACI KASIM \\ Iskenderun Technical University, Department of Aviation Management, Turkey \\ BAKIR MAHMUT \\ Eskişehir Technical University, Department of Aviation Management, Turkey
}

\begin{abstract}
:
In the airline industry where intense competition has taken place, performance evaluation is vital for airlines to achieve their goals and to gain a competitive advantage. This study aims to evaluate the performance of airlines based on the role of performance evaluation in the airline industry. For this purpose, twelve FSCs (Full-Service Carriers) were evaluated based on financial and airline-specific performance indicators for the 2015-2017 period. While the sample consisted of Star Alliance member airlines, an integrated CRITIC and CODAS methodology was proposed in the study. In addition, a sensitivity analysis was performed after the application to examine the accuracy and the stability of the results. The results of the study reveal that financial indicators have a higher impact on performance compared to operational indicators. Moreover, Singapore Airline (SIA) is the best airline regardless of $t$ change.
\end{abstract}

Key words: Strategic Alliances; Airline; Performance; CODAS Method; CRITIC Method

\section{Introduction}

There are many barriers to entry into the markets in the airline industry. Therefore, airlines have applied several strategies to overcome these barriers and thus to operate in global markets. These can be listed as bilateral air service agreements and OpenSky agreements. The first agreement was the Bermuda Agreement, signed between the United States and Britain on February 11, 1946, shortly after the Chicago Convention. After the agreement, many agreements were made to facilitate new entries into the airline markets and to ensure liberalization. For instances, it is seen that the United States has signed 
bilateral Air Services Agreements or Open Skies Agreement with 125 countries $^{1}$ as of 2018.

In order to overcome the financial and legal barriers on entry into the international airline markets, airlines either enter into agreements such as bilateral air service agreements or become members of strategic alliances. According to Vasigh et al. (2013), the agreements have many benefits. These can be listed as the expansion of the flight network by flying to more destinations, falling ticket prices due to increased competition, and overcoming restrictions on entry into the market.

The first Codeshare agreement (Zou and Chen, 2017), considered to be the most common type of strategic alliances, was signed between Air Florida and British Island airlines in 1986 (Vasigh et al., 2013). Over time, Codeshare agreements and strategic alliances have gained great importance, and many airlines have seemed to be involved in these global partnerships. As of 2016, 62 airlines, including 28 in Star Alliance, 20 in SkyTeam, and 14 in Oneworld, involved in a strategic alliance.

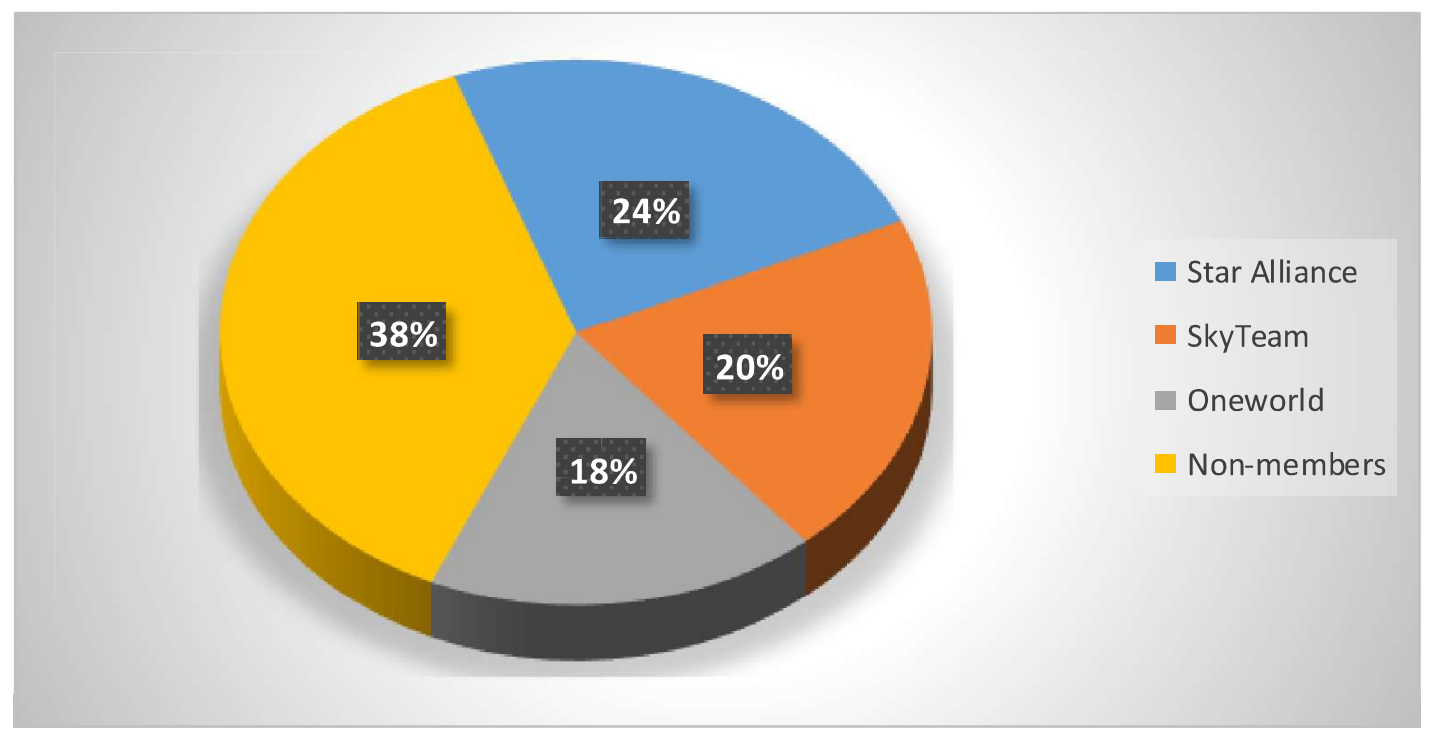

Figure 1: Market Shares of Airline Alliances in 2016 (Airline Business, 2017, s.35)

Figure 1 shows the market share of strategic alliances by 2016. Accordingly, the market share of these strategic alliances were $24 \%, 20 \%$, and $18 \%$ respectively. Airlines, including global partnerships, seem to have $62 \%$ of the total market share.

In Figure 2, revenue, operating income and net profits for the three major global alliances for 2016 are given. Among them, it is seen that Star Alliance had the highest net profit share in 2016.

It is expected that this study, which examines the financial and operational performance of the member companies of Star Alliance, will contribute to the literature in many ways. First, no studies have been found that examine the performance of strategic airline alliances. On the other hand, in addition to the indicators used in all sectors (financial / non-financial), the airline sector has a number of airline-specific key performance indicators (KPIs) such as RPK (Revenue Passenger Kilometers), ASK (Available Seat Kilometers) and load factor (Kalemba et al., 2017). These indicators were

1 For detailed information about the countries involved in the agreement, see: https://www.state.gov/e/eb/rls/othr/ata/267129.htm 
used only in limited studies in the literature. Therefore, this study is noteworthy because it uses financial indicators and the airline-specific KPIs together successfully. Moreover, the integrated CRITIC and CODAS methodology is successfully employed in this case of airlines' performance evaluation.

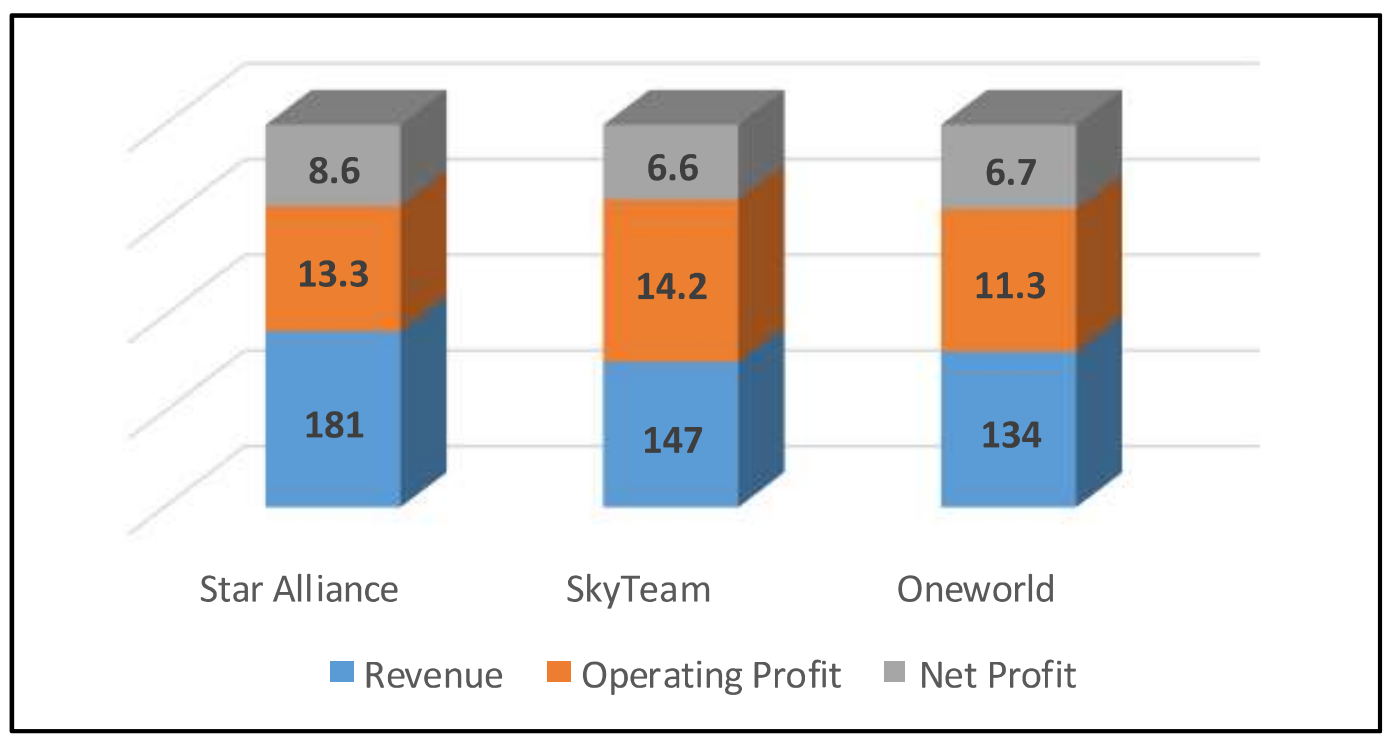

Figure 2: Revenues of Strategic Alliances (\$ Billion) (Airline Business, 2017, s.35)

The rest of the study is organized as follows: In section 2, a literature review is given on airline strategic alliances. In section 3, the integrated methodology is presented, and the procedures are given. In section 4 , a case study on financial and operational performance evaluation is conducted on Star Alliance member airlines. Then, sensitivity analysis is applied to validate the analysis. Finally, in section 5, findings are discussed and suggestions for further studies is presented.

\section{Literature Review}

There are many studies in the literature on strategic airline alliances. Wang (2014) examined the impact of global alliances on buying behavior of passengers. Yimga (2017) investigated whether being involved in a strategic alliance influenced on-time performance. Tiernan et al. (2008) conducted a study to measure the service quality of member airlines in strategic alliances.

There are also many studies on the strategic alliance choice for airlines or partner selection in global alliances. For example, Chao and Kao (2015) examined the global cargo alliance through the Fuzzy Delphi method. Liou et al. (2011) examined partner selection in strategic alliances by Analytical Network Process (ANP) method, and Garg (2016) examined partner selection in strategic alliances by Analytical Hierarchy Process (AHP) and Fuzzy TOPSIS methods.

On the other hand, the literature on the impact of strategic airline alliances on performance is quite narrow. Accordingly, Park and Cho (1997) examined the impact of membership in strategic alliances on airline performance and market structure. Oum et al. (2004) investigated the impact of membership in global alliances on productivity and 
profitability. Similarly, Lazzarini (2007) examined the impact of being a member of alliances on operational performance, and Kuzminykha and Zufan (2014) examined the influence of alliances on airline performance. In addition, there are several studies that investigated the impact of involvement in strategic alliances on airline profitability (Douglas and Tan, 2017; Zou and Chen, 2017). However, no study has been found on the performance evaluation in strategic alliances by using financial and operational performance metrics in airlines.

\section{Scope of Research and Methodology Design}

\subsection{Scope of Research}

As in all industries, for sustainable and commercial success, performance should be monitored frequently, and improvements should be made in the airline industry. In this study, the financial and operational performance of airlines, known as Full-Service Carriers (FSC), was analyzed based on the financial and operations KPIs. In this direction, twelve airlines were investigated in this study for the period of 2015-2017. In addition to the Thomson Reuters Eikon database, Airline Business magazine's annual sector analysis reports and the airline's annual reports were used to collect financial and operational data. Airlines included in the performance evaluation are listed in Table 1.

\section{Table 1: Airlines in Performance Evaluation}

\begin{tabular}{lcc}
\hline Airline & ICAO Code & Passenger Carried (Thousands) (2017) \\
\hline AIR CANADA & ACA & 48,100 \\
AIR CHINA & CCA & 66,100 \\
AIR NEW ZEALAND & ANZ & 16,000 \\
ANA HOLDINGS & AKX & 53,900 \\
ASIANA AIRLINES & AAR & 19,300 \\
AVIANCA & AVA & 29,500 \\
COPA HOLDINGS & CMP & 9,500 \\
LUFTHANSA & DLH & 66,200 \\
SINGAPORE AIRLINES & SIA & 19,500 \\
THAI AIRWAYS & OEA & 20,000 \\
TURK HAVA YOLLARI & THY & 68,600 \\
UNITED CONTINENTAL & UAL & 148,100 \\
\hline
\end{tabular}

As given in Table 1, the study sample contains a large airline cluster, including airlines carried less than 10 million passengers, as well as airlines carried more than 100 million passengers. In this study, liquidity ratios, leverage ratios, activity ratios and profitability ratios were used as financial performance indicators based on the previous studies. Operational performance indicators also imply major airline-specific KPIs. The financial and operational performance indicators used in the study and the way they are calculated are given in Table 2.

\section{Table 2: Performance Indicators Used In Research}

\begin{tabular}{ll}
\hline Code & Financial and Operational Performance Indicators \\
\hline F1 & Liquid Assets / Short-term Liabilities \\
F2 & Liquid Assets-Inventories / Short-term Liabilities \\
F3 & Total Debt / Total Assets \\
F4 & Total Debt / Equity
\end{tabular}


F5 Tangible Fixed Assets / Equity

F6 Total Assets / Equity

F7 Short term Liabilities / Total Assets

F8 Long-term Liabilities / Total Assets

F9 Net Sales / Total Assets

F10 Net Sales / Equity

F11 Net Profit / Equity

F12 Net Profit / Total Assets

F13 Gross Profit / Net Sales

01 Number of employees

02 Available Seat Miles (ASK)

O3 Revenue Passenger Kilometers (RPK)

O4 Load factor

O5 Number of passengers carried

O6 Fleet size

\subsection{Methodology}

\section{The CRITIC Method}

Diakoulaki et al. (1995) developed the CRITIC method. According to the Diakoulaki et al., criteria weights are based on the calculation of the contrast intensity and conflict between criteria (Diakoulaki et al., 1995). When the standard deviation determines the contrast intensity between the criteria, the conflict between the criteria is measured by the correlation coefficient (Zardari et al., 2015; Rostamzadeh et al., 2018). In addition, in the CRITIC method, criteria weights are only determined by the initial decision matrix.

The CRITIC method has been successfully applied in many studies. Firstly, Diakoulaki et al. (1995) used for performance evaluation in the Greek pharmaceutical industry. In the later years, it used in a number of studies such as inter-company performance evaluation with financial ratios by Deng et al. (2000), determination of the value of different savings banks in Spain by Bellver et al (2011), assessment of cities on carbon emissions intensity reduction targets in China by Zhang and Hao (2015), evaluation of the sustainability performance of high-tech enterprises in Taiwan by Hsu et al. (2015), selection of non-traditional manufacturing method by Madić and Radovanović (2015), and prioritization of railway connections planned by TCDD (Turkish State Railways) investment decisions by Kılıç and Çerçioğlu (2016).

The CRITIC method consists of the following steps (Jahan et al., 2012; Madić and Radovanović, 2015):

Step 1. Construction of the decision matrix: In the CRITIC method, the decision matrix is formed first. Since the decision matrix contains information on the decision problem, all the calculations are carried out on the decision matrix without the need for expert opinions (Eq.1).

$$
X=\left[x_{i j}\right]=\left[\begin{array}{cccc}
x_{11} & x_{12} & \ldots & x_{1 n} \\
x_{21} & x_{22} & \ldots & x_{2 n} \\
\ldots & \ldots & \ldots & \ldots \\
x_{m 1} & x_{m 2} & \ldots & x_{m n}
\end{array}\right]
$$


Step 2. Normalization of the decision matrix: In the second step, the normalization process is applied by using Eq. (2) in order to eliminate the anomalies. The benefit/cost type of the criteria are not considered in the process.

$$
r_{i j}=\frac{x_{i j}-x_{j}^{\min }}{x_{j}^{\max }-x_{j}^{\min }}
$$

Step 3. Calculation of the correlation coefficients between the criterion pairs: In this step, the correlation coefficient between the criterion pairs is calculated by using Eq. (3).

$$
\rho_{j k}=\frac{\sum_{i=1}^{m}\left(r_{i j}-\bar{r}_{j}\right)\left(r_{i k}-\bar{r}_{k}\right)}{\sqrt{\sum_{i=1}^{m}\left(r_{i j}-\bar{r}_{j}\right)^{2} \sum_{i=1}^{m}\left(r_{i k}-\bar{r}_{k}\right)^{2}}}
$$

In the third step, the type of correlation analysis can vary according to the data structure. Accordingly, the Pearson correlation or Spearman rank correlation analysis can be applied.

Step 4. Calculation of the total amount of information $\left(c_{j}\right)$ : The total amount of information $\left(c_{j}\right)$ in each criterion is calculated by using Eq. (4). In this calculation, the standard deviation $\left(\sigma_{j}\right)$ values are considered.

$$
c_{j}=\sigma_{j} \sum_{k=1}^{n}\left(1-\rho_{j k}\right)
$$

Based on Eq. (4), it is assumed that the criterion having the highest $\left(\sigma_{j}\right)$ value and having the lowest $\left(\rho_{j k}\right)$ value contains the highest level of information (Madic and Radovanović, 2015).

Step 5. Obtaining the criteria weights: In the final step of the CRITIC method, the weighting coefficients $\left(w_{j}\right)$ of the $j$. criterion are calculated. By using Eq. (5), it is agreed that the criterion with the highest value of $w_{j}$ is the most important criterion. As $w_{j}$ decreases, the relevant criterion becomes less important.

$$
w_{j}=c_{j} / \sum_{k=1}^{n} c_{k}
$$

\section{The CODAS Method}

Combinative Distance-based Assessment (CODAS) method is an MCDM (MultiCriteria Decision Making) method proposed by Ghorabaee et al. (2016). Accordingly, the performance of the alternatives is measured based on Euclidean and Taxicab distances. In addition, the negative ideal solution (NIS) is used (Peng and Garg, 2018; Badi et al., 2018). At this point, the higher value of the distance from the (NIS) is desirable (Mathew and Sahu, 2018). In the CODAS method, the Euclidean distance is used as the primary measure in the evaluation phase. If two alternatives are incomparable according to the Euclidean distance, then Taxicab distance is applied to bring out the best alternative (Ghorabaee et al., 2016). The equality degree of the Euclidean distance is set using a parameter.

In the literature, it is seen that CODAS method has been applied successfully in various studies. In this context, Ghorabaee et al. (2016) used CODAS method for industrial robot selection and evaluation of office microclimate. In order to test the validity of the 
method, a sensitivity analysis was performed with commonly used and validated methods such as WASPAS, COPRAS, TOPSIS, VIKOR, and EDAS. As a result, it was determined that the CODAS method gives successful results. Mathew and Sagu (2018) used CODAS, EDAS, WASPAS and MOORA methods to select the most suitable alternative for the selection of material handling equipment. Badi et al. (2018) successfully used the CODAS method in a supplier selection for a steelmaking company in Libya. In addition, Ghorabaee et al. (2017) extended the CODAS method to the fuzzy logic methodology to assess the market segment in order to come up with the uncertainties of decision-making problems. Boltürk (2018) used the CODAS method with Pythagorean fuzzy sets for supplier selection for a manufacturing firm. Panchal et al. (2017) applied a methodology based on fuzzy AHP and fuzzy CODAS methods for the solution of a maintenance decision in the urea fertilizer industry. Pamučar et al. (2018) proposed an approach in the field of the selection of powergeneration technology by using CODAS method based on linguistic neutrosophic numbers.

The CODAS method can be summarized as follows (Ghorabaee et al., 2016; Badi et al., 2018; Mathew and Sahu, 2018).

Step 1. Construction of the decision matrix: In the first step, the decision matrix is established.

$$
X=\left[x_{i j}\right]_{n x m}=\left[\begin{array}{cccc}
x_{11} & x_{12} & \ldots & x_{1 m} \\
x_{21} & x_{22} & \ldots & x_{2 m} \\
\cdot & \cdot & . & \cdot \\
x_{n 1} & x_{n 2} & \ldots & x_{n m}
\end{array}\right]
$$

Where $i$. alternative shows performance values according to $j$. criterion.

Step 2. Obtaining the normalized decision matrix: In this step, the normalization process is applied in order to eliminate the anomalies. Eq. (6) is used in this step where linear normalization is applied.

$$
n_{i j}= \begin{cases}\frac{x_{i j}}{\max _{i} x_{i j}} & \text { if } j \in N_{b} \\ \frac{\min _{i} x_{i j}}{x_{i j}} & \text { if } j \in N_{c}\end{cases}
$$

In Eq. (6), the $N_{b}$ and $N_{c}$ values represent the benefit and cost criteria, respectively.

Step 3. Obtaining the weighted normalized decision matrix: In this step, the weighting coefficients $\left(w_{j}\right)$ are transferred to the application. The weights obtained by objective and subjective weighting methods are included in the calculation by using Eq. (7).

$$
r_{i j}=w_{j} n_{i j}
$$

Step 4. Calculation of the negative-ideal solution: In this step, the negative-ideal solution is created. By using Eq. (8), the minimum values of column elements in the weighted matrix is calculated.

$$
n s=\left[n s_{j}\right]_{1, x m} \quad n s_{j}=\min _{i} r_{i j}
$$

Step 5. Calculation of the Euclidean $\left(E_{i}\right)$ and Taxicab $\left(T_{i}\right)$ distances: Distance values are calculated to measure the distance of the alternatives from the negative-ideal solution. The Euclidean and Taxicab distances of alternatives from the negative-ideal solution are calculated by using Eq. (9) and Eq. (10), respectively.

$$
E_{i}=\sqrt{\sum_{j=1}^{m}\left(r_{i j}-n s_{j}\right)^{2}}
$$




$$
T_{i}=\sum_{j=1}^{m}\left|r_{i j}-n s_{j}\right|
$$

Step 6. Establishment of the relative assessment matrix: In this step, each alternative is compared to the others based on the Euclidean and Taxicab distance values. Eq. (11) is used in the formation of the relative assessment matrix.

$$
\begin{aligned}
& R_{a}=\left[h_{i k}\right]_{n x n} \\
& h_{i k}=\left(E_{i}-E_{k}\right)+\left(\psi\left(E_{i}-E_{k}\right) \times\left(T_{i}-T_{k}\right)\right) \\
& \psi(x)= \begin{cases}1 & \text { if }|x| \geq \tau \\
0 & \text { if }|x|<\tau\end{cases}
\end{aligned}
$$

In the above function, $\mathrm{T}$ is a threshold parameter set by the decision makers. It is suggested to set this parameter between 0.01 and 0.05 (Ghorabaee et al., 2016). If the difference between the Euclidean distances of the two alternatives is less than $\mathrm{T}$, the relevant alternatives are compared with the Taxicab distances.

Step 7. Calculation of the final assessment score of alternatives: In the last step of the CODAS method, the final assessment score of each alternative is calculated by using Eq. (12).

$$
H_{i k}=\sum_{k=1}^{n} h_{i k}
$$

The alternative having the highest $H$ values is accepted as the most desirable alternative.

\section{Empirical Case Study and Findings}

In this section, a performance analysis case study has been performed using financial and operational indicators. The research period covers between 2015-2017 years. Moreover, the sample is composed of 12 airlines from Star Alliance global alliance, and 20 financial and operational indicators/criteria are used.

\subsection{The Proposed Research Methodology}

The proposed research methodology is shown in Figure 3.

As shown in Figure 3, firstly, airline alternatives and evaluation criteria are determined and the data collection process begins. In the next step, the importance levels of the criteria are determined by using the CRITIC method. It is decided to use the CRITIC method because it takes into account the high degree of dependence between the criteria (Gao et al., 2017). Indeed, the criteria used in the case study have a high degree of dependency with each other. For example, load factor can be seen a commercial output of the airline. Airlines can reduce the operating unit cost by increasing the load factor. In other words, airlines can make more profits if they have a higher load factor (Kalemba et al., 2017).

In the next step, the CODAS method is used. Although the study covers the period between the years 2015-2017, application steps are conducted in detail on the sample for 2017. On the other hand, criteria weights are calculated for each year since the criteria weights could be different every year, and the weight coefficients are transferred to the CODAS method. 


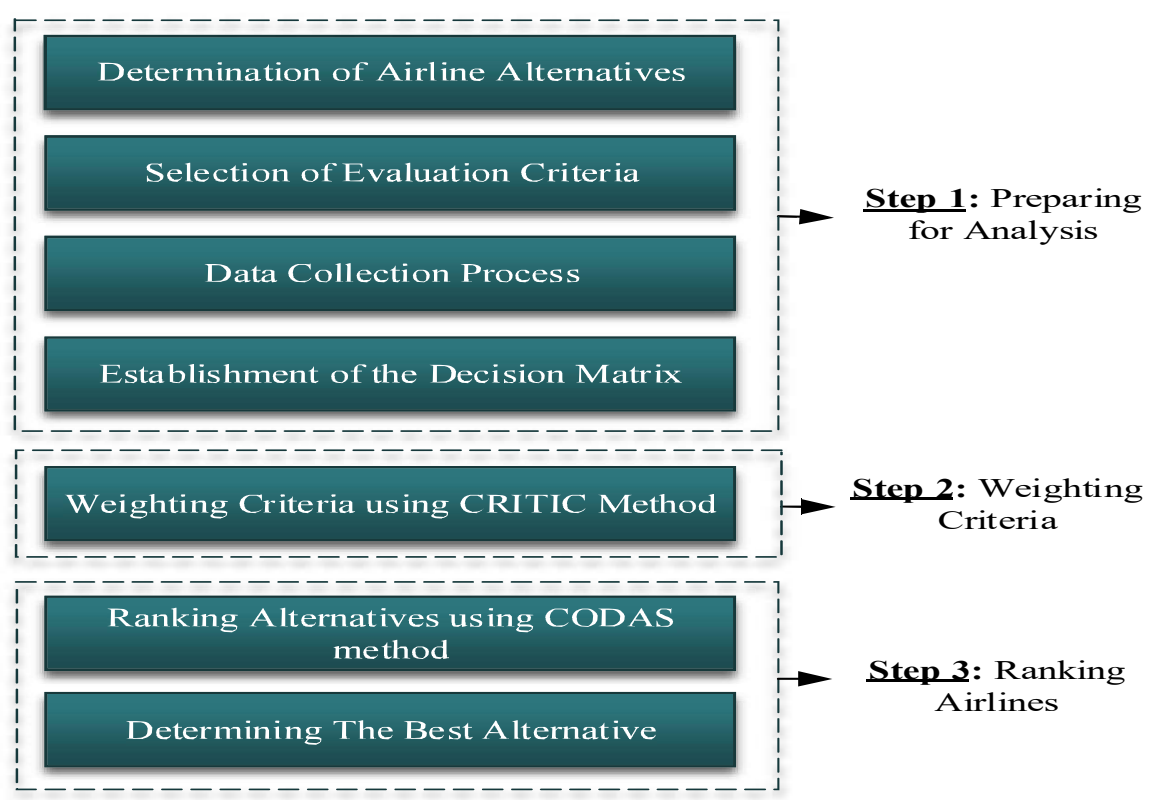

Figure 3. The Framework of the Proposed Research Methodology

\subsection{Determination of Criteria Weights}

The initial decision matrix is given in Appendix A1. Accordingly, the case study involves 12 airlines and 20 criteria in the decision matrix. In terms of benefit/cost characteristics of the criteria, the benefit criteria are highlighted in blue color and the cost criteria are highlighted in red. The decision matrix is normalized by using Eq. (2) in the next step. The normalized decision matrix is given in Appendix A2. The standard deviation $\left(\sigma_{j}\right)$ values, which are indexes of contrast intensity, are also given on the same matrix.

Then, the Spearman's rank coefficient correlation analysis is applied to calculate the dependency between the criteria by using Eq. (3). As an application procedure, the total amount of information $\left(c_{j}\right)$ is calculated by using Eq. (4) after the calculation of correlation coefficients. Finally, the calculation of the criteria weights $\left(w_{j}\right)$ is performed by using Eq. (5). In this context, the values of $\left(c_{j}\right)$ and $\left(w_{j}\right)$ for 2017 are given in Appendix A3. Finally, the criteria weights are transferred to the next step.

\subsection{Performance Analysis through CODAS Method}

In this section, the performance analysis is carried out T the CODAS method. In this direction, the criteria weights are transferred by using Eq. (7) and the decision matrix in Appendix A1 is used. Then, the normalization process is applied by using Eq. (6). Since the evaluation criteria consist of the benefit/cost type criteria, the normalization process is carried out by this distinction and the normalized decision matrix is given in Appendix A4. As shown in Appendix A4, the initial decision matrix elements are normalized by using the maximum and minimum values of each column. For example Air Canada's normalization process for the $\mathrm{F} 1$ criterion is as follows;

$n_{A 1 F 1}=\frac{x_{i j}}{\max x_{i j}}=\frac{0.228}{1.1643}=0.247$ 
After the normalization process, criteria weights are added to the application. This procedure is conducted by using Eq. (7). The weighted decision matrix is given in Appendix A5. After the weighting process, the negative-ideal solution for each criterion is created in the same matrix by using Eq. (8). Next, Euclidean and Taxicab distances are calculated to determine the distance of the alternatives from the negative-ideal solution. In this calculation, it is assumed that the desired criterion is the furthest distance from the negative-ideal solution. The Euclidean $\left(E_{i}\right)$ and Taxicab $\left(T_{i}\right)$ distance values obtained by Eq. (9) and Eq. (10) are given in Appendix A6.

After calculating the values of $\left(E_{i}\right)$ and $\left(T_{i}\right)$, each alternative is compared to the other alternatives in terms of their distances. The relative assessment matrix, which is a square matrix, is created by using Eq. (11). A threshold parameter $(\mathrm{T})$ is used in the calculation for the degree of proximity of the Euclidean distance. The decision maker determines this value, which can affect the calculation dramatically. As in previous studies (Ghorabaee et al., 2016; Mathew and Sahu, 2018; Badi et al., 2018; Boltürk, 2018), we adopted 0.02 as threshold in this study. It means that if the difference between the Euclidean distances of the alternatives is less than 0.02 , the alternatives are compared according to the Taxicab distances. The relative assessment matrix constructed in the study is given in Appendix A7.

As shown in Appendix A7, the alternatives are compared by $\tau=0.02$ and then $H_{i}$ values are obtained by using Eq. (12). Using the values of $\left(E_{i}\right)$ and $\left(T_{i}\right)$ belong to Air China-Air Canada alternatives, the value of $H_{i}$ is calculated as follows;

$$
\begin{gathered}
\psi(x)=\left\{\begin{array}{ll}
1 & \text { if }|x| \geq \tau \\
0 & \text { if }|x|<\tau
\end{array} \quad \text { and }\left(E_{i}-E_{k}\right)=(x)=|0.0584-0.0848|=0.0264>0.02\right. \\
h_{i k}=\left(E_{i}-E_{k}\right)+\left(\psi\left(E_{i}-E_{k}\right) \times\left(T_{i}-T_{k}\right)\right)=(0.0584-0.0848)+(|1| x(0.1833-0.2718)) \\
=(-0.0264)+(-0.0885)=-0.1149
\end{gathered}
$$

The findings reveal that Singapore Airlines has the highest $H_{i}$ value and thus the best performing airline is Singapore Airlines. On the other hand, the worst performing airline is Air China. A sensitivity analysis was also applied to demonstrate the validity and stability of the ranking. In this context, 14 different threshold parameters between 0.01 and 1.00 were used for ranking and it was investigated whether the change of $\mathrm{T}$ value is a significant effect on the ranking. Table 3 shows the different $T$ values and their effect on

\begin{tabular}{|c|c|c|c|c|c|c|c|c|c|c|c|}
\hline & \multicolumn{11}{|c|}{$\tau$} \\
\hline & 0.01 & 0.02 & 0.03 & 0.04 & 0.05 & $\ldots$ & 0.1 & 0.15 & 0.3 & 0.5 & 1.00 \\
\hline$\overline{\mathrm{ACA}}$ & 7 & 7 & 7 & 6 & 6 & & 6 & 6 & 6 & 6 & 6 \\
\hline CCA & 12 & 12 & 12 & 12 & 12 & & 12 & 12 & 12 & 12 & 12 \\
\hline ANZ & 4 & 4 & 5 & 5 & 5 & & 5 & 5 & 5 & 5 & 5 \\
\hline ANA & 5 & 5 & 4 & 3 & 3 & & 3 & 3 & 3 & 3 & 3 \\
\hline AAR & 11 & 10 & 10 & 10 & 10 & & 10 & 10 & 10 & 10 & 10 \\
\hline AVA & 10 & 11 & 11 & 11 & 11 & $\ldots$ & 11 & 11 & 11 & 11 & 11 \\
\hline CMP & 2 & 2 & 2 & 2 & 2 & & 2 & 2 & 2 & 2 & 2 \\
\hline DLH & 6 & 6 & 6 & 7 & 7 & & 7 & 7 & 7 & 7 & 7 \\
\hline SIA & 1 & 1 & 1 & 1 & 1 & & 1 & 1 & 1 & 1 & 1 \\
\hline THA & 9 & 8 & 8 & 8 & 8 & & 8 & 8 & 8 & 8 & 8 \\
\hline THY & 8 & 9 & 9 & 9 & 9 & & 9 & 9 & 9 & 9 & 9 \\
\hline UAL & 3 & 3 & 3 & 4 & 4 & & 4 & 4 & 4 & 4 & 4 \\
\hline
\end{tabular}
airline ranking.

Table 3: Airline Ranking with Different $\tau$ Values 
The results of the sensitivity analysis are also illustrated in Figure 4. It is obvious that Singapore Airline (SIA) is the best airline regardless of $\mathrm{T}$ change. On the other hand, it is found that the change of the $T$ parameter does not significantly change the ranking of alternatives.
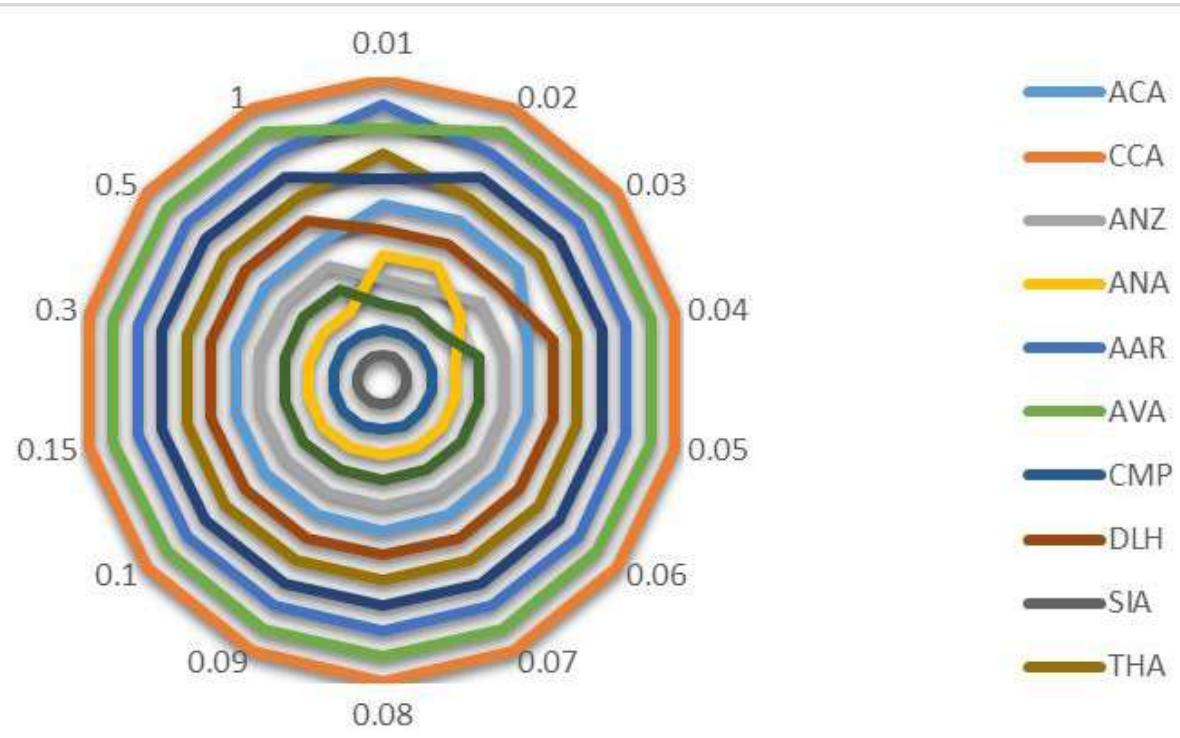

Figure 4. The Effect of the Different Values of $\mathrm{T}$ on Ranking

In this study covering the years 2015-2017, as the case study is applied only on 2017 data, the performance ranking for 2015-2017 is given in Table 4. In addition, the total performance of the airlines and the change in the ranking is illustrated in Figure 5.

Table 4: Airline Performance Ranking by Years

\begin{tabular}{lcccccc}
\hline & \multicolumn{2}{c}{$\mathbf{2 0 1 5}$} & \multicolumn{2}{c}{$\mathbf{2 0 1 6}$} & \multicolumn{2}{c}{$\mathbf{2 0 1 7}$} \\
\cline { 2 - 7 } & $\boldsymbol{H}_{i}$ & Ranking & $\boldsymbol{H}_{i}$ & Ranking & $\boldsymbol{H}_{i}$ & Ranking \\
\hline ACA & 0.6741 & 5 & 0.5939 & 5 & -0.0829 & 7 \\
CCA & -1.0343 & 8 & -1.0162 & 9 & -1.2795 & 12 \\
ANZ & 0.8129 & 3 & 0.8233 & 3 & 0.2104 & 4 \\
ANA & -0.1669 & 6 & -0.1656 & 6 & 0.1329 & 5 \\
AAR & -1.1356 & 10 & -1.0802 & 10 & -0.9523 & 10 \\
AVA & -1.2264 & 11 & -1.1030 & 11 & -1.0816 & 11 \\
CMP & 1.4414 & 2 & 1.5426 & 2 & 1.8078 & 2 \\
DLH & -0.2599 & 7 & -0.3520 & 7 & -0.0309 & 6 \\
SIA & 2.4730 & 1 & 2.3506 & 1 & 1.9951 & 1 \\
THA & -1.0670 & 9 & -0.9861 & 8 & -0.4946 & 8 \\
THY & -1.2737 & 12 & -1.2599 & 12 & -0.6349 & 9 \\
UAL & 0.7625 & 4 & 0.6526 & 4 & 0.4106 & 3 \\
\hline
\end{tabular}




\section{Studies in Business and Economics no. 15(1)/2020}

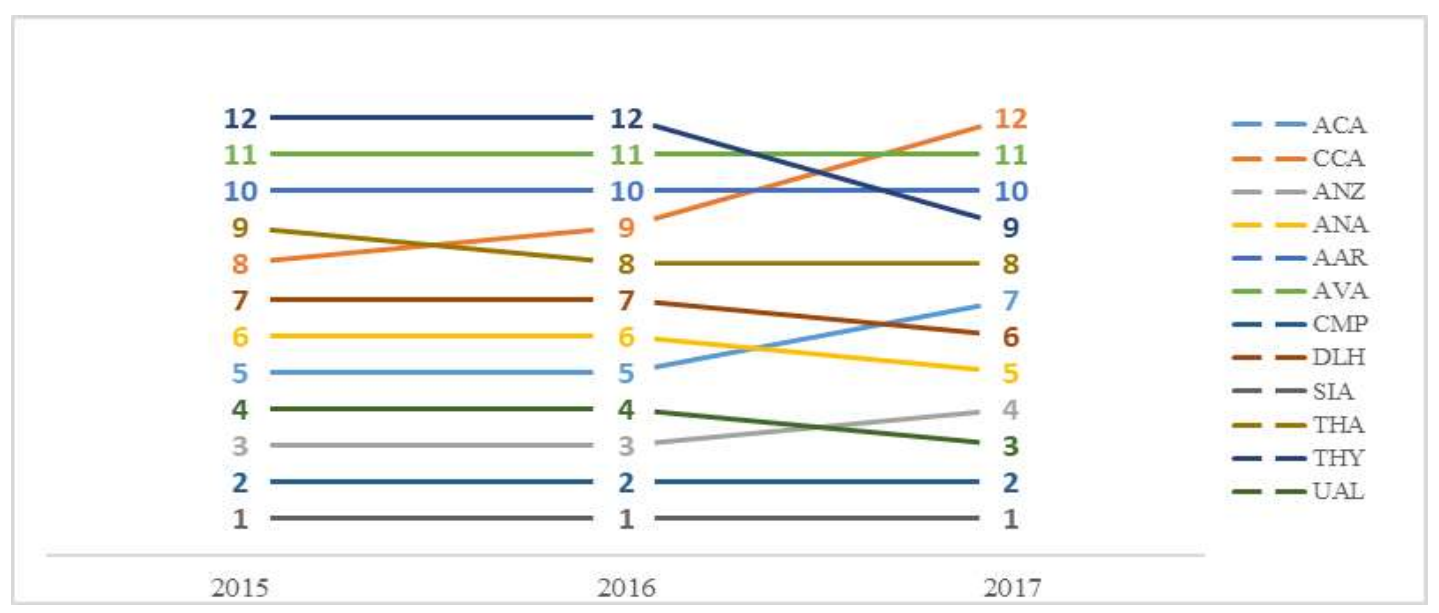

Figure 5. Airline Performance Ranking For the 2015-2017 Period

Both Table 4 and Figure 5 reveal that the performance of the airlines during the period $2015-2017$ is largely stable and the ranking changes slightly. In addition, Spearman's rank coefficient correlation analysis was performed on the final performance rankings, and all coefficients were larger than 0.88 . This validates that the ranking is stable.

\section{Conclusion}

The concept of performance is multi-dimensional in nature and is influenced by many factors. The types of performance measurements in the firms are generally financial performance, service quality performance, and operational performance including a number of sectoral characteristics. Considering the performance evaluation literature, it is seen that the ratio analysis based on financial ratios and the use of the statistical methods such as regression analysis are common (Çakır and Perçin, 2013). As the performance measurement is a multidimensional structure (Yıldız et al., 2011), other alternative methods that can be used are the MCDM methods. Since performance measurement often involves many factors that conflict with each other, it is quite convenient to use the MCDM methods, which are seen as a solution to the complexity of decision making in today's business world.

In this study, an integrated model of CRITIC and CODAS methodology is proposed in evaluating the performance of Star Alliance member airlines. In this context, the CRITIC method is used to find the objective weights and the CODAS method is used to rank airlines. The application steps were explained in detail over the year 2017 sample. Finally, sensitivity analysis was applied. The findings reveal that the most important criteria are F2, F6, and F1, respectively. It implies that the financial structure ratios, and the liquidity ratios, are important for airline companies. Following the CRITIC method, it is found that Singapore Airlines is best performing airline. Moreover, Copa Holdings ranks second, and United Continental Airlines ranks third. Air China, on the other hand, has the lowest performance. Finally, a sensitivity analysis was applied to observe the effect of the $\mathrm{T}$ parameter change. Accordingly, at different parameters ranging from 0.01 to 1.00 , the variation of the rankings remains at a very low level. In the period covering 2015-2017 
years, Singapore Airlines and Copa Holdings airlines are in the same order, while other airlines have minor changes.

As the airline industry grows, the growing intense competition forces businesses to measure their performances and to take new steps to improve. It is important for airline managers that the results provide an idea of which criteria are more important for airlines and allow businesses to see their status within an airline cluster. On the other hand, it is seen that performance studies in businesses have mainly focused on financial performance indicators. Therefore, it is considered that the performance evaluation of airlines using the MCDM methods will provide some contributions to the literature. Theoretically, the main contributions of this study are as follows: a) Financial and operational KPIs were used as integrated, b) A limited number of studies contributed to the literature of airline alliances in previous studies, c) the integrated CRITIC-CODAS methodology was applied successfully.

As in all studies, this study is not exempt from limitations. First, only the data from the Thomson Reuters database was used. Second, the study evaluated airlines' performance only according to the identified criteria. Therefore, it should be noted that if different criteria are used, the ranking may change. Third, in order to limit the scope of the study, the case study was applied only on Star Alliance member airlines. Fourth, findings should not be generalized since the study represents only a limited number of FSCs. Finally, it should be kept in mind that even if the methods used in the study change, there may be changes in the ranking.

Finally, we can provide some suggestions for further studies. Since the concept of performance is multidimensional, it is appropriate to employ different performance indicators in future studies. On the other hand, hybrid or low-cost airlines can be analyzed by considering the business model. Thus, the results can provide deep insights with analyzes based on the business models. Multivariate statistical methods can be used to find some new relationships or similarities by expanding the sample in the study. In addition, more robust and successful integrated models can be developed. Finally, authors can contribute to the enrichment of literature by using intuitionistic fuzzy numbers, rough numbers, and interval numbers.

\section{References}

Airline Business. (2017). Special Report Alliances. Reed Business Information Ltd.

Badi, I. A., Abdulshahed, A. M., \& Shetwan, A. G. (2018). A case study of supplier selection for a steelmaking company in Libya by using the Combinative Distance-Based Assessment (CODAS) Model. Decision Making: Applications in Management and Engineering, 1(1), 1-12.

Bellver, J. A., Royo, R. C., \& Garcia, F. G. (2011). Spanish savings banks and their future transformation into private capital banks. determining their value by a multicriteria valuation methodology. European Journal of Economics, Finance and Administrative Sciences, 35, 156-164.

Boltürk, E. (2018). Pythagorean fuzzy CODAS and its application to supplier selection in a manufacturing firm. Journal of Enterprise Information Management, 31(4), 550-564.

Chao, C. C., \& Kao, K. T. (2015). Selection of Strategic Cargo Alliance by Airlines. Journal of Air Transport Management(43), 29-36.

Çakır, S., \& Perçin, S. (2013). Çok Kriterli Karar Verme Teknikleriyle Lojistik Firmalarında Performans Ölçümü. Ege Akademik Bakış, 13(4), 449-459. 
Deng, H., Yeh, C. H., \& Willis, R. J. (2000). Inter-company comparison using modified TOPSIS with objective weights. Computers\& Operations Research, 27(10), 963-973.

Diakoulaki, D., Mavrotas, G., \& Papayannakis, L. (1995). Determining objective weights in multiple criteria problems: The critic method. Computers \& Operations Research, 22(7), 763-770.

Douglas, I., \& Tan, D. (2017). Global Airline Alliances and Profitability: A Difference-In-Difference Analysis. Transportation Research Part A: Policy and Practise(103), 432-443.

Gao, R., Nam, H. O., Ko, W. I., \& Jang, H. (2017). National Options for a Sustainable Nuclear Energy System: MCDM Evaluation Using an Improved Integrated Weighting Approach. Energies(10), $1-24$.

Garg, C. P. (2016). A Robust Hybrid Decision Model for Evaluation and Selection of the Strategic Alliance Partner in the Airline Industry. Journal of Air Transport Management(52), 55-66.

Ghorabaee, M. K., Amiri, M., Zavadskas, E. K., Hooshmand, R., \& Antucheviciene, J. (2017). Fuzzy Extension of The CODAS Method For Multi-Criteria Market Segment Evalution. Journal of Business Economics and Management, 18(1), 1-19.

Ghorabaee, M. K., Zavadskas, E. K., Turskis, Z., \& Antucheviciene, J. (2016). A New Combinative Distance-Based Assessment (CODAS) Method For Multi-Criteria Decision Making. Economic Computation and Economic Cybernetics Studies and Research, 3(50), 25-44.

Hsu, L. C., Ou, S. L., \& Ou, Y. C. (2015). A Comprehensive performance evaluation and ranking methodology under a sustainable development perspective. Journal of Business Economics and Management, 16(1), 74-92.

Jahan, A., Mustapha, F., Sapuan, S. M., Ismail, M. Y., \& Bahraminasab, M. (2012). A framework for weighting of criteria in ranking stage of material selection process. The International Journal of Advanced Manufacturing Technology, 58(1-4), 411-420.

Kalemba, N., Campa-Planas, F., Hernández-Lara, A. B., \& Sánchez-Rebull, M. V. (2017). Service quality and economic performance in the US airline business. Aviation, 21(3), 102-110.

Kılıç, O., \& Çerçioğlu, H. (2016). TCDD İltisak Hatları Projelerinin Değerlendirilmesinde Uzlaşık Çok Kriterli Karar Verme Yöntemleri Uygulaması. Gazi Üniversitesi Mühendislik Mimarlık Fakültesi Dergisi, 31(1), 211-220.

Kuzminykh, N., \& Zufan, P. (2014). Airline Alliances and Their Influence on Firm Performance. Procedia Economics and Finance(12), 329-333.

Lazzarini, S. G. (2007). The impact of membership in competing alliance constellations: Evidence on the operational performance of global airlines. Strategic Management Journal, 28(4), 345367.

Liou, J. J., Tzeng, G. H., Tsai, C. Y., \& Hsu, C. C. (2011). A Hybrid ANP Model in Fuzzy Environments for Strategic Alliance Partner Selection in the Airline Industry. Applied Soft Computing, 11(4), 3515-3524.

Madić, M., \& Radovanović, M. (2015). Ranking of Some Most Commonly Used Non-Traditional Machining Process Using ROV and CRITIC Methods. U.P.B. Sci. Bull., Series D, 77(2), 193204.

Mathew, M., \& Sahu, S. (2018). Comparison of new multi-criteria decision making methods for matiral handling equipment selection. Management Science Letters, 8(3), 139-150.

Oum, T. H., Park, J. H., Kim, K., \& Yu, C. (2004). The Effect of Horizontal Alliances on Firm Productivity and Profitability: Evidence from the Global Airline Industry. Journal of Business Research, 57(8), 844-853.

Pamučar, D., Badi, I., Sanja, K., \& Obradović, R. (2018). A Novel Approach for the Selection of Power-Generation Technology Using a Linguistic Neutrosophic CODAS method. Energies, 11(9), 1-25.

Panchal, D., Chatterjee, P., Shukla, R. K., Choudhury, T., \& Tamosaitiene, J. (2017). Integrated fuzzy AHP-CODAS framework for maintenance decision in urea fertilizer industry. Economic computation and economic cybernetics studies and research, 51, 179-196. 


\section{Studies in Business and Economics no. 15(1)/2020}

Park, N. K., \& Cho, D. S. (1997). The Effect of Strategic Alliance on Performance: A Study of International Airline Industry. Journal of Air Transport Management, 3(3), 155-164.

Peng, X., \& Garg, H. (2018). Algorithms for interval-valued fuzzy soft sets in emergency decision making based on WDBA and CODAS with new information measure. Computers\& Industrial Engineering, 119, 439-452.

Rostamzadeh, R., Ghorabaee, M. K., Govindan, K., Esmaeili, A., \& Nobar, H. B. (2018). Evaluation of sustainable supply chain risk management using an integrated Fuzzy TOPSIS-CRITIC approach. Journal of Cleaner Production(175), 651-669.

TDK. (2018). Güncel Türkçe Sözlük. Retrieved Ağustos 15, 2018, from Türk Dil Kurumu: http://www.tdk.gov.tr/index.php?option=com_gts\&arama=gts\&guid=TDK.GTS.5b8b9f19e93a2 8.85094897

Tiernan, S., Rhoades, D., \& Waguespack, B. (2008). Airline Alliance Service Quality Performancean Analysis of US and EU Member Airlines. Journal of Air Transport Management, 14(2), 99102.

Trinkūnienè, E., Podvezko, V., Zavadskas, E. K., Jokšienè, I., Vinogradova, I., \& Trinkūnas, V. (2017). Evaluation of quality assurance in contractor contracts by multi-attribute decisionmaking methods. Economic Research-Ekonomska Istraživanja, 30(1), 1152-1180.

Vasigh, B., Fleming , K., \& Tacker, T. (2013). Introduction to Air Transport Economics: From Theory to Applications (2. ed.). Ashgate Publishing Company.

Wang, S. W. (2014). Do global airline alliances influence the passenger's purchase decision? Journal of Air Transport Management, 37, 53-59.

Yıldız, F., Hotamışlı, M., \& Eleren, A. (2011). Construction of Multi Dimensional Performance Measurement Model in Business Organizations: An Empirical Study. Journal of Economic\& Social Studies, 1(1), 33-51.

Yimga, J. O. (2017). Airline Code-Sharing and Its Effects on On-Time Performance. Journal of Air Transport Management(58), 76-90.

Zardari, N. H., Ahmed, K., Shirazi, S. M., \& Yusop, Z. B. (2015). Weighting Methods and Their Effects on Multi-Criteria Decision Making Model Outcomes in Water Resources Management . London: Springer International Publishing.

Zhang, J. Y., \& Hao, J. F. (2015). The allocation of carbon emission intensity reduction target by 2020 among provinces in China. Natural Hazards, 79(2), 921-937.

Zou, L., \& Chen, X. (2017). The Effect of Code-Sharing Alliances on Airline Profitability. Journal of Air Transport Management(58), 50-57. 
Appendix:

Appendix A1. Initial Decision Matrix

\begin{tabular}{|c|c|c|c|c|c|c|c|c|c|c|c|c|c|c|c|c|c|c|c|c|}
\hline & $F_{1}$ & $F 2$ & $F_{3}$ & F4 & F5 & $F_{6}$ & F7 & $\mathrm{FB}$ & F9 & F10 & F11 & $F 12$ & $F 13$ & 01 & 02 & 03 & 04 & 05 & O6 & 07 \\
\hline ACA & 0.288 & 0.273 & 0.355 & 2.446 & 2.031 & 0.145 & 0.028 & 0.316 & 0.843 & 6.497 & 0.557 & 0.081 & 0.456 & 28300 & 136885 & 160519 & 82.3 & 48.1 & 174 & 68.1 \\
\hline CCA & 0.288 & 0.267 & 0.407 & 1.102 & 2.197 & 0.368 & 0.150 & 0.257 & 0.532 & 1.441 & 0.137 & 0.051 & 0.393 & 27858 & 147165 & 181887 & 80.8 & 86.1 & 401 & 80.5 \\
\hline ANZ & 0.785 & 0.748 & 0.351 & 1.266 & 2.388 & 0.277 & 0.044 & 0.308 & 0.712 & 2.573 & 0.278 & 0.076 & 0.473 & 10890 & 34814 & 42168 & 82.6 & 16.0 & 58 & 76.8 \\
\hline ANA & 1.164 & 1.051 & 0.323 & 0.784 & 1.480 & 0.408 & 0.052 & 0.270 & 0.781 & 1.921 & 0.158 & 0.064 & 0.238 & 39243 & 89405 & 122803 & 72.8 & 53.8 & 224 & 119.3 \\
\hline AAR & 0.345 & 0.278 & 0.538 & 3.831 & 4.681 & 0.137 & 0.253 & 0.288 & 0.741 & 5.411 & 0.240 & 0.033 & 0.141 & 11480 & 44211 & 53947 & 820 & 19.3 & 83 & 98.5 \\
\hline AVA & 0.685 & 0.614 & 0.548 & 2.650 & 3.448 & 0.207 & 0.084 & 0.485 & 0.644 & 3.110 & 0.206 & 0.043 & 0.381 & 19278 & 40243 & 48401 & 83.1 & 28.5 & 181 & 86.7 \\
\hline CMP & 1.132 & 1.055 & 0.277 & 0.558 & 1.338 & 0.498 & 0.070 & 0.207 & 0.597 & 1.187 & 0.208 & 0.104 & 0.588 & 9045 & 32042 & 32512 & 83.2 & 8.5 & 88 & 54.2 \\
\hline DLH & 0.873 & 0.801 & 0.197 & 0.720 & 1.911 & 0.273 & 0.020 & 0.177 & 1.024 & 3.747 & 0.241 & 0.068 & 0.420 & 128424 & 153188 & 187782 & 81.6 & 60.2 & 343 & 189.4 \\
\hline SIA & 0.908 & 0.878 & 0.063 & 0.120 & 1.250 & 0.528 & 0.002 & 0.062 & 0.801 & 1.136 & 0.048 & 0.025 & 0.088 & 25194 & 95855 & 118127 & 81.1 & 19.5 & 108 & 87.2 \\
\hline THA & 0.555 & 0.501 & 0.590 & 4.994 & 5.895 & 0.118 & 0.119 & 0.471 & 0.703 & 5.950 & 0.142 & 0.017 & 0.067 & 20855 & 68102 & 85388 & 79.8 & 20.0 & 84 & 63.7 \\
\hline THY & 0.845 & 0.800 & 0.498 & 1.696 & 2.432 & 0.294 & 0.095 & 0.403 & 0.578 & 1.986 & 0.138 & 0.041 & 0.125 & 31510 & 136947 & 173073 & 79.1 & 68.6 & 310 & 80.5 \\
\hline UAL & 0.561 & 0.488 & 0.340 & 1.634 & 2.976 & 0.208 & 0.040 & 0.300 & 0.892 & 4.285 & 0.417 & 0.087 & 0.247 & 70238 & 347983 & 422179 & 82.4 & 148.1 & 744 & 807 \\
\hline
\end{tabular}

Appendix A2. Normalized Decision Matrix

\begin{tabular}{|c|c|c|c|c|c|c|c|c|c|c|c|c|c|c|c|c|c|c|c|c|}
\hline & F1 & F2 & F3 & $\mathrm{F} 4$ & F5 & $\mathrm{F} 6$ & F7 & F8 & F9 & F10 & F11 & $\mathrm{F} 12$ & $\mathrm{~F} 13$ & 01 & 02 & 03 & 04 & 05 & 06 & 07 \\
\hline ACA & 0.000 & 0.009 & 0.554 & 0.477 & 0.187 & 0.086 & 0.097 & 0.622 & 0.836 & 1.000 & 1.000 & 0.736 & 0.745 & 0.180 & 0.332 & 0.334 & 0.913 & 0.278 & 0.172 & 0.082 \\
\hline CCA & 0.000 & 0.000 & 0.652 & 0.201 & 0.203 & 0.610 & 0.589 & 0.477 & 0.000 & 0.057 & 0.175 & 0.388 & 0.626 & 0.156 & 0.364 & 0.374 & 0.779 & 0.408 & 0.501 & 0.250 \\
\hline ANZ & 0.587 & 0.612 & 0.545 & 0.235 & 0.244 & 0.386 & 0.109 & 0.587 & 0.387 & 0.268 & 0.448 & 0.684 & 0.778 & 0.015 & 0.009 & 0.010 & 0.942 & 0.047 & 0.000 & 0.155 \\
\hline ANA & 1.000 & 0.995 & 0.482 & 0.138 & 0.048 & 0.701 & 0.202 & 0.510 & 0.505 & 0.146 & 0.217 & 0.546 & 0.330 & 0.251 & 0.182 & 0.220 & 0.000 & 0.320 & 0.244 & 0.448 \\
\hline AAR & 0.085 & 0.015 & 0.902 & 0.782 & 0.734 & 0.048 & 1.000 & 0.547 & 0.425 & 0.798 & 0.377 & 0.185 & 0.142 & 0.020 & 0.039 & 0.040 & 0.885 & 0.071 & 0.039 & 0.305 \\
\hline AVA & 0.430 & 0.441 & 0.922 & 0.519 & 0.473 & 0.216 & 0.327 & 0.985 & 0.228 & 0.368 & 0.310 & 0.296 & 0.603 & 0.085 & 0.026 & 0.026 & 0.980 & 0.144 & 0.182 & 0.224 \\
\hline CMP & 0.964 & 1.000 & 0.406 & 0.090 & 0.018 & 0.926 & 0.274 & 0.355 & 0.132 & 0.011 & 0.315 & 1.000 & 1.000 & 0.000 & 0.000 & 0.000 & 1.000 & 0.000 & 0.048 & 0.000 \\
\hline DLH & 0.687 & 0.678 & 0.253 & 0.123 & 0.141 & 0.377 & 0.072 & 0.281 & 1.000 & 0.487 & 0.380 & 0.565 & 0.677 & 1.000 & 0.383 & 0.389 & 0.846 & 0.409 & 0.417 & 1.000 \\
\hline SIA & 0.706 & 0.776 & 0.000 & 0.000 & 0.000 & 1.000 & 0.000 & 0.000 & 0.141 & 0.000 & 0.000 & 0.099 & 0.042 & 0.134 & 0.202 & 0.208 & 0.798 & 0.072 & 0.077 & 0.227 \\
\hline THA & 0.305 & 0.297 & 1.000 & 1.000 & 1.000 & 0.000 & 0.486 & 1.000 & 0.347 & 0.898 & 0.184 & 0.000 & 0.000 & 0.096 & 0.114 & 0.122 & 0.673 & 0.076 & 0.041 & 0.086 \\
\hline THY & 0.636 & 0.677 & 0.828 & 0.323 & 0.254 & 0.427 & 0.371 & 0.834 & 0.093 & 0.155 & 0.178 & 0.276 & 0.246 & 0.187 & 0.332 & 0.351 & 0.806 & 0.426 & 0.378 & 0.043 \\
\hline UAL & 0.312 & 0.281 & 0.525 & 0.311 & 0.371 & 0.219 & 0.153 & 0.582 & 0.731 & 0.587 & 0.725 & 0.804 & 0.346 & 0.508 & 1.000 & 1.000 & 0.923 & 1.000 & 1.000 & 0.182 \\
\hline$\sigma$ & 0.346 & 0.364 & 0.293 & 0.298 & 0.302 & 0.335 & 0.276 & 0.286 & 0.316 & 0.354 & 0.270 & 0.307 & 0.321 & 0.282 & 0.278 & 0.278 & 0.274 & 0.279 & 0.286 & 0.268 \\
\hline
\end{tabular}

Appendix A3. Criteria Weights

\begin{tabular}{|c|c|c|c|c|c|c|c|c|c|c|}
\hline & F1 & $F 2$ & $\mathrm{~F} 3$ & $F 4$ & $\mathrm{~F} 5$ & F6 & F7 & F8 & F9 & F10 \\
\hline \multirow{3}{*}{$w_{i}$} & 7.4065 & 7.8961 & 5.5778 & 5.6778 & 5.7118 & 7.8129 & 5.6751 & 5.2534 & 4.9456 & 6.0197 \\
\hline & 0.0675 & 0.0720 & 0.0509 & 0.0518 & 0.0521 & 0.0712 & 0.0517 & 0.0479 & 0.0451 & 0.0549 \\
\hline & F11 & $F 12$ & $F 13$ & 01 & 02 & 03 & 04 & 05 & 06 & 07 \\
\hline $\begin{array}{c}c_{f} \\
w_{1}\end{array}$ & $\begin{array}{l}4.3259 \\
0.0394\end{array}$ & $\begin{array}{l}5.2940 \\
0.0483\end{array}$ & $\begin{array}{l}6.0236 \\
0.0549\end{array}$ & $\begin{array}{l}4.5218 \\
0.0412\end{array}$ & $\begin{array}{l}4.3599 \\
0.0398\end{array}$ & $\begin{array}{l}4.3713 \\
0.0399\end{array}$ & $\begin{array}{l}5.1756 \\
0.0472\end{array}$ & $\begin{array}{l}4.2882 \\
0.0391\end{array}$ & $\begin{array}{l}4.4674 \\
0.0407\end{array}$ & $\begin{array}{l}4.8651 \\
0.0444\end{array}$ \\
\hline
\end{tabular}

Appendix A4. Normalized Decision Matrix with CODAS Method

\begin{tabular}{|c|c|c|c|c|c|c|c|c|c|c|c|c|c|c|c|c|c|c|c|c|}
\hline & F1 & F2 & F3 & $\mathrm{F} 4$ & F5 & F6 & $F 7$ & F8 & F9 & $\mathrm{F} 10$ & F11 & $\mathrm{F} 12$ & $\mathrm{~F} 13$ & 01 & $\mathrm{O} 2$ & 03 & 04 & 05 & 06 & 07 \\
\hline A1 & 0.247 & 0.259 & 0.178 & 0.049 & 0.345 & 0.274 & 0.065 & 0.195 & 0.821 & 1.000 & 1.000 & 0.778 & 0.774 & 0.320 & 0.384 & 0.394 & 0.888 & 0.325 & 0.322 & 0.821 \\
\hline A2 & 0.247 & 0.253 & 0.158 & 0.108 & 0.373 & 0.697 & 0.011 & 0.240 & 0.518 & 0.222 & 0.246 & 0.487 & 0.689 & 0.325 & 0.423 & 0.431 & 0.972 & 0.446 & 0.140 & 0.599 \\
\hline A3 & 0.674 & 0.710 & 0.181 & 0.095 & 0.405 & 0.523 & 0.038 & 0.201 & 0.696 & 0.396 & 0.495 & 0.735 & 0.804 & 0.831 & 0.100 & 0.100 & 0.993 & 0.108 & 1.000 & 0.706 \\
\hline A4 & 1.000 & 0.896 & 0.197 & 0.151 & 0.251 & 0.768 & 0.032 & 0.228 & 0.782 & 0.298 & 0.284 & 0.618 & 0.408 & 0.230 & 0.257 & 0.291 & 0.875 & 0.364 & 0.250 & 0.454 \\
\hline A5 & 0.296 & 0.284 & 0.118 & 0.030 & 0.791 & $0.25 \theta$ & 0.007 & 0.216 & 0.724 & 0.833 & 0.430 & 0.316 & 0.240 & 0.787 & 0.127 & 0.128 & 0.986 & 0.130 & 0.875 & 0.550 \\
\hline A6 & 0.571 & 0.582 & 0.118 & 0.045 & 0.585 & 0.391 & 0.020 & 0.133 & $0.62 \theta$ & 0.479 & 0.368 & 0.410 & 0.648 & 0.468 & 0.116 & 0.115 & 0.899 & 0.198 & 0.308 & 0.825 \\
\hline A7 & 0.973 & 1.000 & 0.228 & 0.215 & 0.227 & 0.942 & 0.024 & 0.298 & 0.583 & 0.184 & 0.374 & 1.000 & 1.000 & 1.000 & 0.092 & 0.081 & 1.000 & 0.084 & 0.628 & 1.000 \\
\hline A8 & 0.750 & 0.758 & 0.323 & 0.187 & 0.324 & 0.518 & 0.086 & 0.349 & 1.000 & 0.577 & 0.433 & 0.635 & 0.714 & 0.070 & 0.440 & 0.445 & 0.981 & 0.447 & 0.163 & 0.272 \\
\hline A9 & 0.779 & 0.832 & 1.000 & 1.000 & 0.213 & 1.000 & 1.000 & 1.000 & 0.587 & 0.175 & 0.086 & 0.244 & 0.151 & 0.359 & 0.275 & 0.280 & 0.975 & 0.132 & 0.514 & 0.622 \\
\hline A10 & 0.477 & 0.475 & 0.107 & 0.024 & 1.000 & 0.223 & 0.014 & 0.131 & 0.686 & 0.916 & 0.255 & 0.181 & 0.114 & 0.438 & 0.196 & 0.202 & 0.959 & 0.135 & 0.687 & 0.851 \\
\hline A11 & 0.726 & 0.758 & 0.127 & 0.071 & 0.413 & 0.555 & 0.018 & 0.153 & 0.584 & 0.303 & 0.250 & 0.393 & 0.332 & 0.287 & 0.394 & 0.410 & 0.951 & 0.463 & 0.177 & 0.896 \\
\hline A12 & 0.482 & 0.463 & 0.187 & 0.073 & 0.505 & 0.393 & 0.042 & 0.206 & 0.871 & 0.660 & 0.748 & 0.835 & 0.420 & $0.12 \theta$ & 1.000 & 1.000 & 0.990 & 1.000 & 0.075 & 0.872 \\
\hline
\end{tabular}

Appendix A5. The Weighted Decision Matrix and the Negative-Ideal Solution

\begin{tabular}{|c|c|c|c|c|c|c|c|c|c|c|c|c|c|c|c|c|c|c|c|c|}
\hline & F1 & F2 & F3 & F4 & F5 & F6 & F7 & F8 & F9 & $\mathrm{F} 10$ & F11 & $\mathrm{F} 12$ & $\mathrm{~F} 13$ & 01 & 02 & 03 & 04 & 05 & 06 & 07 \\
\hline A1 & 0.017 & 0.018 & 0.000 & 0.003 & 0.018 & 0.020 & 0.003 & 0.000 & 0.042 & 0.055 & 0.038 & 0.038 & 0.043 & 0.013 & 0.018 & 0.016 & 0.047 & 0.013 & 0.013 & 0.036 \\
\hline A2 & 0.017 & 0.018 & 0.008 & 0.000 & 0.018 & 0.050 & 0.001 & 0.012 & 0.023 & 0.012 & 0.010 & 0.023 & 0.037 & 0.013 & 0.017 & 0.017 & 0.046 & 0.017 & 0.000 & 0.027 \\
\hline A3 3 & 0.046 & 0.051 & 0.000 & 0.005 & 0.021 & 0.037 & 0.002 & 0.010 & 0.031 & 0.022 & 0.020 & 0.035 & 0.044 & 0.034 & 0.004 & 0.004 & 0.047 & 0.004 & 0.041 & 0.031 \\
\hline A4 & 0.068 & 0.072 & 0.010 & 0.008 & 0.013 & 0.055 & 0.002 & 0.011 & 0.034 & 0.016 & 0.011 & 0.030 & 0.022 & 0.010 & 0.010 & 0.012 & 0.041 & 0.014 & 0.010 & 0.020 \\
\hline A5 & 0.020 & 0.018 & 0.006 & 0.002 & 0.041 & 0.018 & 0.000 & 0.010 & 0.033 & 0.048 & 0.017 & 0.015 & 0.013 & 0.032 & 0.005 & 0.005 & 0.047 & 0.005 & 0.027 & 0.024 \\
\hline A6 & 0.039 & 0.042 & 0.008 & 0.002 & 0.030 & 0.028 & 0.001 & 0.006 & 0.028 & 0.026 & 0.015 & 0.020 & 0.036 & 0.018 & 0.005 & 0.005 & 0.047 & 0.008 & 0.013 & 0.028 \\
\hline A7 & 0.086 & 0.072 & 0.012 & 0.011 & 0.012 & 0.087 & 0.001 & 0.014 & 0.026 & 0.010 & 0.015 & 0.048 & 0.055 & 0.041 & 0.004 & 0.004 & 0.047 & 0.003 & 0.020 & 0.044 \\
\hline A8 & 0.051 & 0.055 & 0.018 & 0.000 & 0.017 & 0.037 & 0.004 & 0.017 & 0.045 & 0.032 & 0.017 & 0.031 & 0.039 & 0.003 & 0.017 & 0.018 & 0.048 & 0.017 & 0.007 & 0.012 \\
\hline A9 & 0.053 & 0.080 & 0.051 & 0.052 & 0.011 & 0.071 & 0.052 & 0.048 & 0.026 & 0.010 & 0.003 & 0.012 & 0.008 & 0.015 & 0.011 & 0.011 & 0.046 & 0.005 & 0.021 & 0.028 \\
\hline A10 & 0.032 & 0.034 & 0.005 & 0.001 & 0.052 & 0.016 & 0.001 & 0.006 & 0.031 & 0.050 & 0.010 & 0.008 & 0.008 & 0.018 & 0.008 & 0.008 & 0.045 & 0.005 & 0.027 & 0.038 \\
\hline A11 & 0.049 & 0.055 & 0.006 & 0.004 & 0.021 & 0.040 & 0.001 & 0.007 & 0.025 & 0.017 & 0.010 & 0.019 & 0.018 & 0.012 & 0.018 & 0.016 & 0.045 & 0.018 & 0.007 & 0.040 \\
\hline A12 & 0.033 & 0.033 & 0.000 & 0.004 & 0.026 & 0.028 & 0.002 & 0.010 & 0.038 & 0.036 & 0.030 & 0.040 & 0.023 & 0.005 & 0.040 & 0.040 & 0.047 & 0.039 & 0.003 & 0.030 \\
\hline MS & 0.017 & 0.018 & 0.005 & 0.001 & 0.011 & 0.016 & 0.000 & 0.006 & 0.023 & 0.010 & 0.003 & 0.008 & 0.006 & 0.003 & 0.004 & 0.004 & 0.041 & 0.003 & 0.003 & 0.012 \\
\hline
\end{tabular}


Studies in Business and Economics no. 15(1)/2020

Appendix A6. The Distances of the Alternatives from the Negative-Ideal Solution

\begin{tabular}{lcc}
\hline & $E_{i}$ & $T_{i}$ \\
\hline ACA & 0.0848 & 0.2718 \\
CCA & 0.0584 & 0.1833 \\
ANZ & 0.0894 & 0.3036 \\
ANA & 0.0918 & 0.2739 \\
AAR & 0.0654 & 0.1920 \\
AVA & 0.0605 & 0.2080 \\
CMP & 0.1238 & 0.3827 \\
DLH & 0.0816 & 0.2946 \\
SIA & 0.1263 & 0.3984 \\
THA & 0.0739 & 0.2079 \\
THY & 0.0695 & 0.2311 \\
UAL & 0.0905 & 0.3227 \\
\hline
\end{tabular}

Appendix A7. The Relative Assessment Matrix

\begin{tabular}{|c|c|c|c|c|c|c|c|c|c|c|c|c|c|}
\hline & A1 & $\mathrm{A} 2$ & A3 & A4 & A5 & A6 & A7 & A8 & A9 & A10 & A11 & A12 & $H_{i}$ \\
\hline A1 & 0 & 0.115 & -0.005 & -0.007 & 0.019 & 0.088 & -0.150 & 0.003 & -0.168 & 0.011 & 0.015 & -0.006 & -0.083 \\
\hline A2 & -0.115 & 0 & -0.151 & -0.124 & -0.007 & -0.002 & -0.265 & -0.135 & -0.283 & -0.016 & -0.011 & -0.172 & -1.280 \\
\hline A3 & 0.005 & 0.151 & 0 & -0.002 & 0.136 & 0.125 & -0.114 & 0.008 & -0.132 & 0.016 & 0.020 & -0.001 & 0.210 \\
\hline A4 & 0.007 & 0.124 & 0.002 & 0 & 0.108 & 0.097 & -0.141 & 0.010 & -0.159 & 0.018 & 0.065 & 0.001 & 0.133 \\
\hline A5 & -0.019 & 0.007 & -0.136 & -0.108 & 0 & 0.005 & -0.249 & -0.016 & -0.267 & -0.009 & -0.004 & -0.156 & -0.952 \\
\hline A6 & -0.088 & 0.002 & -0.125 & -0.097 & -0.005 & 0 & -0.238 & -0.108 & -0.256 & -0.013 & -0.009 & -0.145 & -1.082 \\
\hline A7 & 0.150 & 0.265 & 0.114 & 0.141 & 0.249 & 0.238 & 0 & 0.130 & -0.003 & 0.225 & 0.206 & 0.093 & 1.808 \\
\hline A8 & -0.003 & 0.135 & -0.008 & -0.010 & 0.016 & 0.108 & -0.130 & 0 & -0.149 & 0.008 & 0.012 & -0.009 & -0.031 \\
\hline A9 & 0.168 & 0.283 & 0.132 & 0.159 & 0.267 & 0.256 & 0.003 & 0.149 & 0 & 0.243 & 0.224 & 0.112 & 1.995 \\
\hline A10 & -0.011 & 0.016 & -0.016 & -0.018 & 0.009 & 0.013 & -0.225 & -0.008 & -0.243 & 0 & 0.004 & -0.017 & -0.495 \\
\hline A11 & -0.015 & 0.011 & -0.020 & -0.065 & 0.004 & 0.009 & -0.206 & -0.012 & -0.224 & -0.004 & 0 & -0.113 & -0.635 \\
\hline A12 & 0.006 & 0.172 & 0.001 & -0.001 & 0.156 & 0.145 & -0.093 & 0.009 & -0.112 & 0.017 & 0.113 & 0 & 0.411 \\
\hline
\end{tabular}

